\title{
Dostępność do usług kulturalnych w Meksyku
}

W geografii zagadnienie usług rozpatrywane jest z dwóch różnych punktów widzenia: ich znaczenia ekonomicznego jako składnika całej gospodarki narodowej, a także jako sfery działalności gospodarczej, zaspokajającej określone potrzeby, zarówno produkcji jak i poszczególnych jednostek (Werwicki 1998). Uczestnictwo w kulturze jest efektem zaspokajania potrzeb wyższego rzędu, należących według A. Maslowa do grupy potrzeb związanych z samorealizacją, poczuciem estetyki i wrażliwością (Bywalec, Rudnicki 2002, Rutkowski 1984). Potrzeby i aspiracje społeczeństwa w zakresie kultury stale rosną, są także coraz bardziej zróżnicowane, jest to naturalna konsekwencja rozwoju społecznego i cywilizacyjnego (Prawelska-Skrzypek 2003).

Interesującą i ważną z punktu widzenia planowania oraz polityki regionalnej kwestią jest zróżnicowanie terenu pod względem wyposażenia w usługi. „Dobre usługi, to przede wszystkim usługi dostępne" (Styś 1992, s. 27), ważnym zatem zagadnieniem w badaniach poświęconych usługom jest ich dostępność. Wyższa bądź niższa gęstość i nasycenie placówkami usługowymi na danym obszarze świadczy o poziomie dostępności do tych usług. Zwiększa się w ten sposób atrakcyjność obszaru, przyciagając ludność o określonym (wyższym) statusie społecznym i ekonomicznym. Istnienie na badanym obszarze placówek kulturalnych podnosi również atrakcyjność turystyczną regionu, przyciągając odwiedzających i umożliwiając rozwój innych usług.

W opracowaniu postanowiono zająć się wyposażeniem Meksyku w usługi kulturalne. Dane wykorzystane w analizie pochodzą z bazy danych Instituto Nacional de Estadística, Geografía e Informática (meksykańskiego Urzędu Statystycznego) za okres 2007 r., a także statystyk meksykańskich dotyczących kultury (z 2005 r.). Na tej podstawie zbadano poziom wyposażenia poszczególnych stanów Meksyku w placówki teatralne, kina, muzea (do muzeów w meksykańskiej statystyce zaliczono również galerie, ogrody botaniczne i zoologiczne, akwaria i planetaria), strefy archeologiczne, obiekty, w których odbywają się pokazy z udziałem byków („taurinos”), a także obiekty rekreacyjne. Do tych ostatnich w Meksyku zaliczane są miejsca pokazów rodeo, pokazów na lodzie, wodnych oraz cyrkowych. Dla tych wszystkich kategorii usług kulturalnych obliczono wskaźniki nasycenia, mierzony liczbą osób przypadających na placówkę kulturalną.

Spośród kategorii badanych usług kulturalnych jedynie muzea znajdują się we wszystkich 32 stanach. Najsłabiej reprezentowanymi placówkami są obiekty rekreacyjne (znajdują się w 20 stanach) oraz ,taurinos” (w 23 stanach). Jedynie w 15 spotkać można wszystkie sześć badanych kategorii usług, a w 3 stanach (Morelos, Nayarit i Sonora) zanotowano istnienie tylko trzech rodzajów usług kulturalnych. 


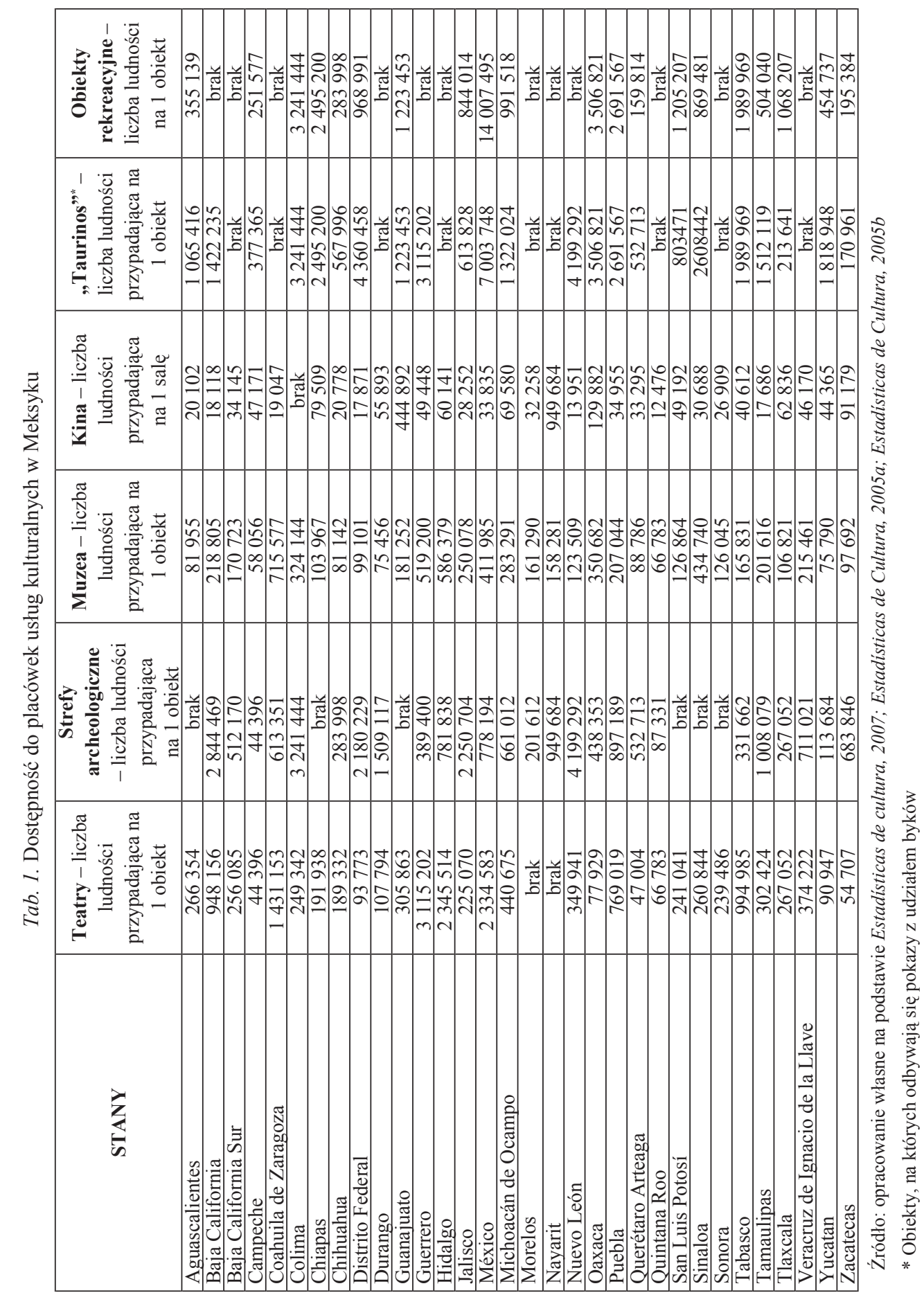


Wartości nasycenia poszczególnych stanów w placówki kulturalne przedstawiono w tabeli 1 . W przypadku dostępności do teatrów zanotowano, iż w badanym okresie $w$ dwóch stanach (Morelos i Nayarit) nie istniały placówki teatralne. Najniższe wartości, świadczące o najlepszej dostępności, charakteryzowały stany położone na Jukatanie, natomiast najgorsza sytuacja panowała w stanach wokół stolicy kraju (Mexico, Hidalgo, Guerrero). Kolejną badaną kategorią były strefy archeologiczne - specyficzne dla tego regionu pozostałości po miastach upadłych cywilizacji (m.in. Majów, Azteków, Olmeków). Tego typu strefy znajdowały się w 26 stanach, najlepsza sytuacja pod tym względem panowała na półwyspie Jukatan i generalnie na południu kraju. Muzea, jak wcześniej wspomniano, reprezentowane były we wszystkich stanach Meksyku, niektóre z nich zlokalizowane były także przy strefach archeologicznych (stanowiły jednak odrębne jednostki statystyczne). Podobnie jak w poprzednich przypadkach, najlepsza sytuacja również dotyczyła Jukatanu, najgorsza natomiast istniała w stanach wzdłuż wybrzeża Pacyfiku. W przypadku dostępności do kin analizowano liczbę ludności przypadającą na 1 salę kinową, ze względu na występowanie w wielu stanach multipleksów. Najlepsza sytuacja pod tym względem panowała w północnej części kraju, w stolicy (stan Distrito Federal) oraz w stanie Quintana Roo (na półwyspie Jukatan), najgorsza (poza stanem Colima, w którym nie było ani jednego kina) w stanie Nayarit. Pokazy „taurinos” odbywają się w specjalnie do tego przystosowanych budynkach. Najwięcej tego typu obiektów w odniesieniu do liczby ludności zanotowano w środkowej części kraju w stanach Zacatecas i Tlaxcala. Natomiast w dziewięciu stanach tego typu placówki w ogóle nie istniały. Obiekty rekreacyjne były spośród badanych najsłabiej reprezentowanymi placówkami kulturalnymi w Meksyku. Najlepiej były dostępne dla mieszkańców na Jukatanie - w stanie Yucatan i Campeche, a także w centralnej części Meksyku.

Zbadano również korzystanie z usług kulturalnych, mierzone liczbą sprzedanych biletów na spektakle w przeliczeniu na 1000 mieszkańców. Największą popularnością w Meksyku cieszyły się spektakle kinowe - średnia wartość dla całego kraju w przeliczeniu na 1000 mieszkańców to aż 1300 biletów. Najrzadziej Meksykanie korzystali ze spektakli „taurinos” - średnia wartość to zaledwie ok. 14 sprzedanych biletów na 1000 mieszkańców. Wartości dotyczące liczbą sprzedanych biletów w przeliczeniu na 1000 mieszkańców prezentuje tabela 2.

Z teatrów najwięcej osób korzystało w stolicy kraju - czyli w Distrito Federal. Wysokie wartości korzystania odnotowano w stanach położonych na Jukatanie - Yucatan i Campeche. Najmniej osób odwiedzało teatry w stanach położonych na południe od stolicy oraz wokół Distrito Federal: w stanie Mexico, Tlaxcala oraz Hidalgo, natomiast w stanie Morelos brak było tego typu placówek. Najwyższe wartości korzystania ze stref archeologicznych dotyczyły południa kraju. Wśród odwiedzających część stanowili obcokrajowcy - według INAH (Instituto Nacional de Antropología e Historia) największy ich odsetek zanotowano w stanie Quintana Roo (aż 3/4 odwiedzających; Indicatores 2008). Wysoki odsetek obcokrajowców wśród odwiedzających dotyczył też takich stanów, jak Chiapas, Baja California Sur i Yucatan (powyżej 40\%). W pozostałych stanach ten odsetek był znacznie niższy. Stan Quintana Roo przodował również pod względem korzystania z muzeów. Również wysokie wartości zanotowano w Distrito Federal. Kolejne stany notowały już znacznie niższą sprzedaż, a minimalne wartości charakteryzowały stany Sinaloa, Coahuila de Zaragoza czy San Luis Potosi. Najpopularniejsze w Meksyku kina szczególnie licznie odwiedzane były w stanach Quintana Roo i Distrito Federal, natomiast najmniej chętnych zanotowano w Nayarit, a także w Guanajuato i Tlaxcala. Pokazy „taurinos” najpopularniejsze były w centralnej części kraju (w stanach: Jalisco, Zacatecas i Queretaro Arteaga), najrzadziej korzystano 


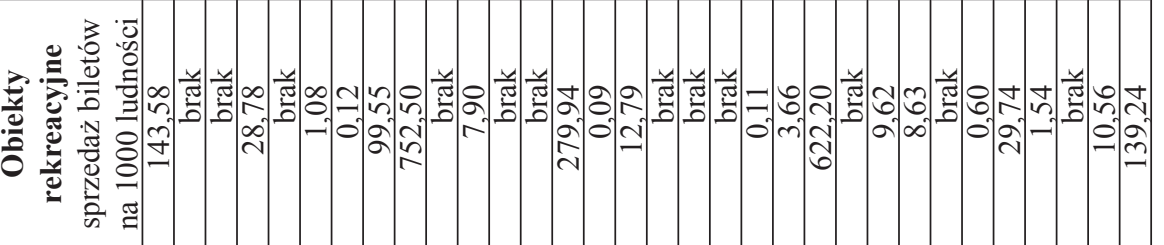

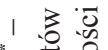

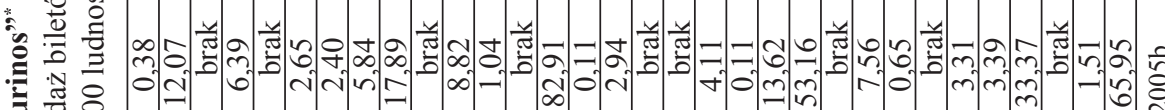
敢

范范

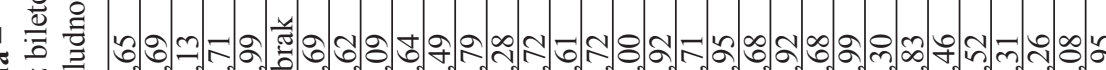

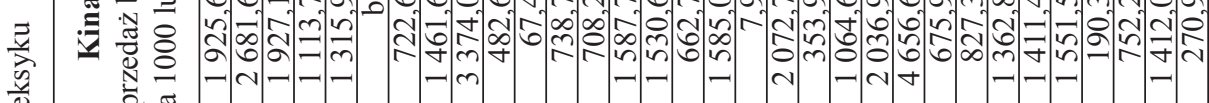

$\frac{1}{0}$

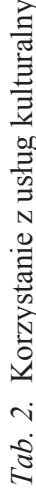

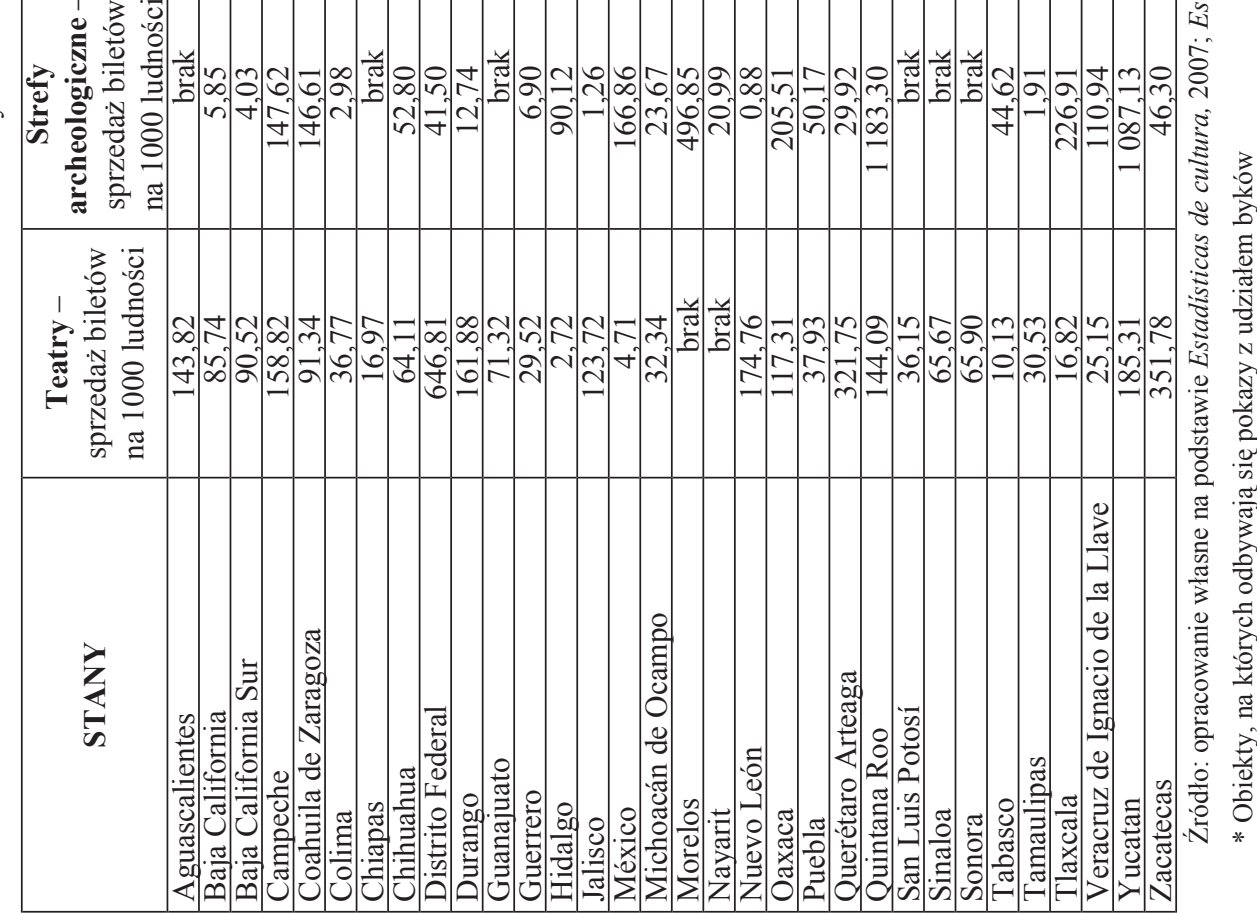


z nich w stanie Mexico i Oaxaca. Ostatnią badaną usługą kulturalną były obiekty rekreacyjne. Najczęściej odwiedzali je mieszkańcy stolicy, najrzadziej (podobnie jak w przypadku „taurinos”) mieszkańcy Mexico i Oaxaca.

Na podstawie analiz stworzono hierarchię stanów meksykańskich pod względem wyposażenia w usługi kulturalne oraz korzystania z tych usług. Przedstawione wcześniej dane poddano standaryzacji, aby możliwe było ich porównanie. Wartości poszczególnych usług po standaryzacji uszeregowano od najwyższej do najniższej. Najlepiej wyposażony stan otrzymywał 32 punkty i wartość ta stopniowo malała. W przypadku gdy dana usługa nie była reprezentowana w stanie, otrzymywał on 0 punktów. Następnie zsumowano wartości punktów przyznawanych w poszczególnych kategoriach usług kulturalnych dla poszczególnych stanów. Ponadto badane usługi podzielono na dwie grupy: I poziom - kina, ,taurinos" oraz obiekty rekreacyjne; II poziom - teatry, muzea i strefy archeologiczne. Zbadano w ten sposób, jaki udział w całości punktów mają usługi „niższe” (I poziom) oraz „wyższe” (II poziom). Następnie wszystkie stany na podstawie sumy uzyskanych punktów uszeregowano w kolejności od najwyższej do najniższej wartości. Tego typu analizę przeprowadzono zarówno dla dostępności, jak i korzystania z usług.

Maksymalnie każdy stan mógł uzyskać 192 punkty za dostępność i tyle samo za korzystanie. Najwięcej punktów pod względem dostępności uzyskał stan Campeche (168 pkt) i Queretaro Arteaga (159 pkt; ryc. 1). W obu przypadkach na tę wartość wpłynęły zarówno wysokie wartości dostępności do usług I i II poziomu. Najniższą dostępnością usług kulturalnych w Meksyku charakteryzowały się stany Hidalgo, Nayarit i Chiapas (uzyskały za-

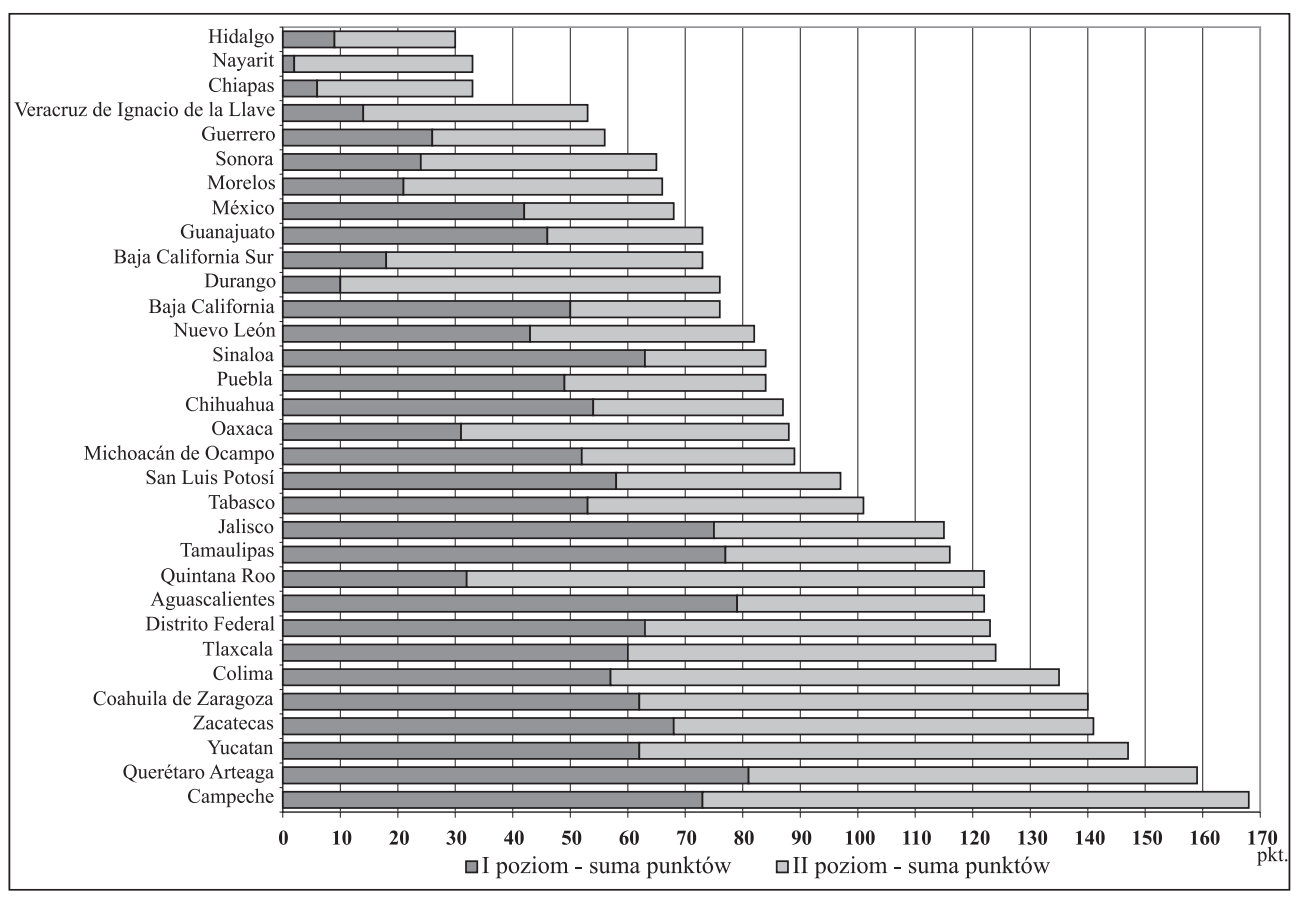

Ryc. 1. Hierarchia stanów meksykańskich pod względem dostępności do usług kulturalnych

Źródło: opracowanie własne na podstawie Estadîsticas de cultura, 2007; Estadîsticas de Cultura, 2005a; Estadîsticas de Cultura, 2005b 
ledwie po ok. 30 pkt.). Przy czym, co ciekawe, większość punktów dotyczyła dostępności do usług II (wyższego) poziomu. Z kolei w przypadku korzystania z usług kulturalnych na pierwszym miejscu w hierarchii uplasowała się oczywiście stolica, uzyskując 172 punkty, na drugim miejscu (podobnie jak w przypadku dostępności) stan Queretaro (uzyskał 152 punkty; ryc. 2). Na końcu hierarchii znalazły się stany znane ze słabej dostępności (czyli Hidalgo i Nayarit), zamieniły się jedynie miejscami.

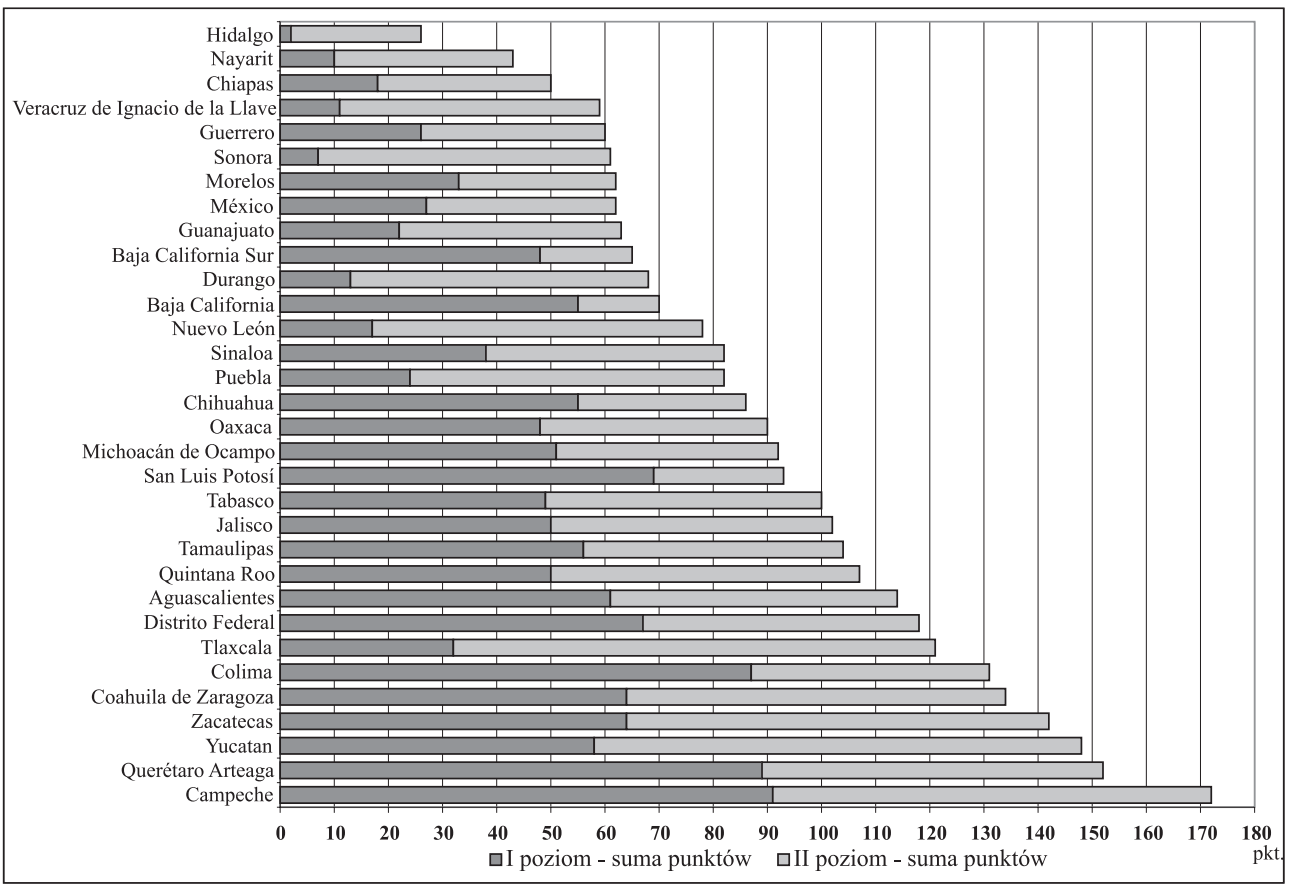

Ryc. 2. Hierarchia stanów meksykańskich pod względem dostępności do usług kulturalnych

Źródło: opracowanie własne na podstawie Estadîsticas de cultura, 2007; Estadîsticas de Cultura, 2005a; Estadîsticas de Cultura, 2005b

W wielu przypadkach jednak zaobserwowano, iż dobra dostępność do usług nie pociągała za sobą wysokiego z nich korzystania. Zanotowano również przypadki, w których pomimo słabej dostępności do usług korzystało z nich wiele osób. Na podstawie sumy uzyskanych w analizie punktów stworzono diagram, na którym po jednej stronie zaznaczono punkty uzyskane w hierarchii dostępności, a po drugiej stronie w hierarchii korzystania z usług kulturalnych (ryc. 3). Ciemniejszy kolor na wykresie oznacza, o ile punktów była wyższa dostępność od korzystania lub korzystanie od dostępności. Wynikiem tej analizy jest kartogram przedstawiający odniesienie poziomu korzystania z usług do rzeczywistej do nich dostępności (ryc. 4). Poziomymi szrafami zaznaczono stany, w których korzystanie z usług kulturalnych było niższe, niż pozwalałaby na to dostępność do nich. Była to przede wszystkim północ kraju. Natomiast odcieniami szarości wyróżniono te obszary, w których korzystanie było zawyżone w stosunku do dostępności do placówek usługowych. Były to głównie stany położone w centralnej części Meksyku. Najwyższą wartość korzystania w stosunku do dostępności zanotowano w Distrito Federal i Puebla (o 49 i 30 pkt więcej), najniższą w Coahuila de Zaragoza (aż 78 pkt mniej). 


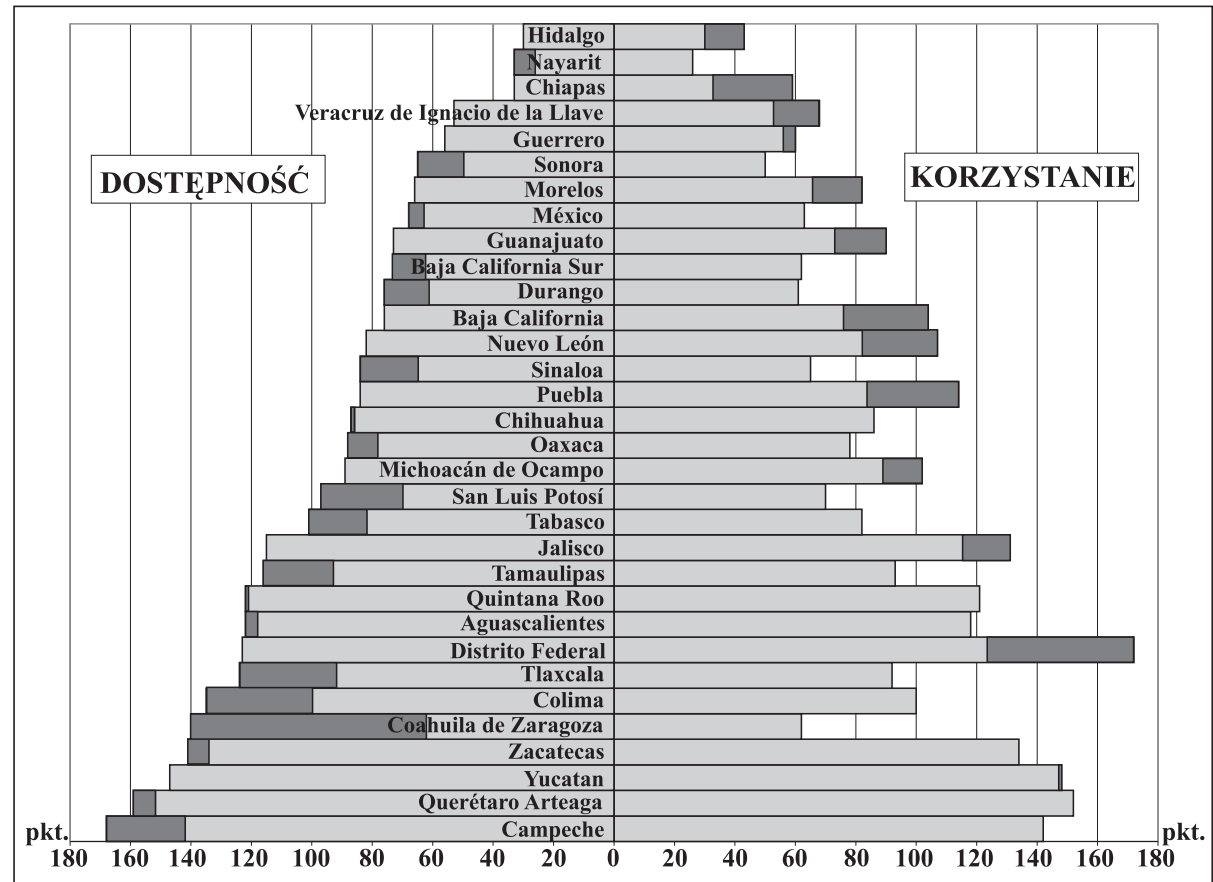

Ryc. 3. Porównanie hierarchii dostępności do usług kulturalnych

i korzystania z tych usług w Meksyku

Źródło: opracowanie własne na podstawie Estadîsticas de cultura, 2007; Estadîsticas de Cultura, 2005a; Estadîsticas de Cultura, 2005b

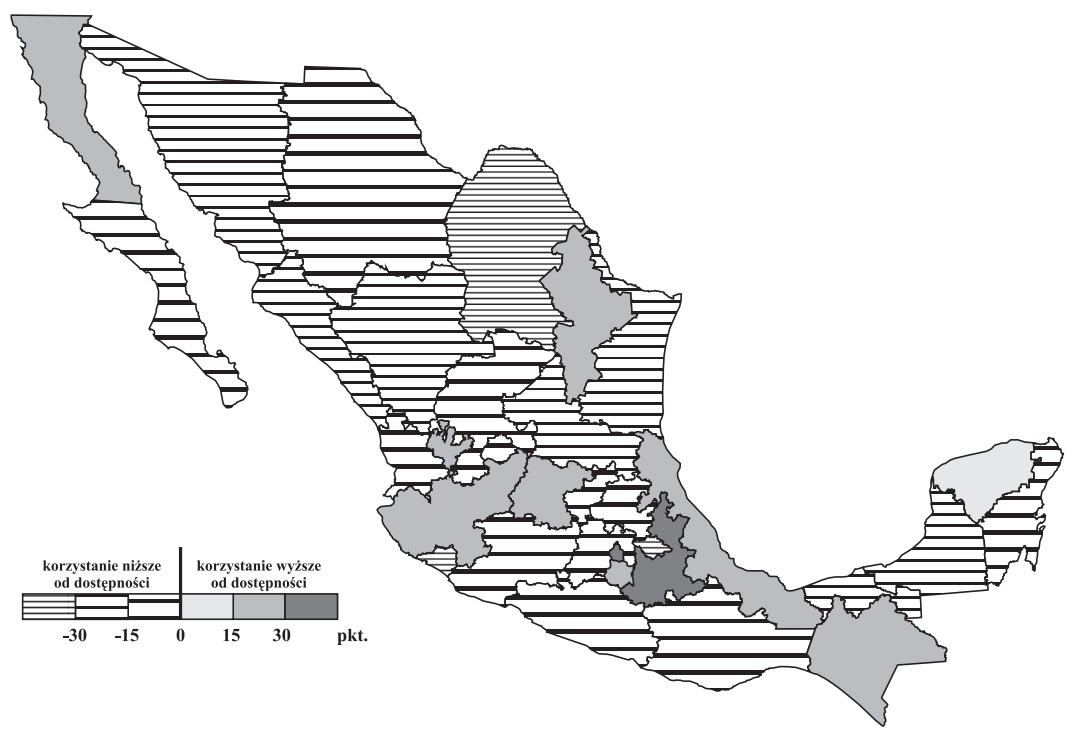

Ryc. 4. Odniesienie poziomu korzystania z usług kulturalnych do dostępności do placówek Źródło: opracowanie własne na podstawie Estadîsticas de cultura, 2007; Estadîsticas de Cultura, 2005a; Estadîsticas de Cultura, 2005b 
W celu wyjaśnienia tych zjawisk postanowiono skorelować wartości korzystania z usług kulturalnych z wybranymi wskaźnikami społecznymi (poziomem urbanizacji, odsetkiem osób z wyższym wykształceniem, odsetkiem osób zatrudnionych w rolnictwie, leśnictwie i rybołówstwie oraz procentem dużych gospodarstw domowych). Zaobserwowano wysoką korelację poziomu urbanizacji z liczbą osób odwiedzających kina, muzea oraz obiekty rekreacyjne. Korzystanie z tych usług koreluje również z odsetkiem osób z wyższym wykształceniem i odsetkiem zatrudnionych w rolnictwie. Wpływ na te same typy usług miała również wielkość gospodarstw domowych (analizowano korelację z gospodarstwami 5-osobowymi i większymi). W przypadku najwyższej wartości zawyżonego korzystania - w Distrito Federal - zaobserwowano również wysoki poziom urbanizacji i wysoki odsetek osób z wyższym wykształceniem oraz niski odsetek mieszkańców zatrudnionych w rolnictwie. W tym stanie obserwowano też stosunkowo niewielki procent dużych gospodarstw domowych. Podobne czynniki miały wpływ na zawyżone korzystanie z usług kulturalnych w stosunku do ich dostępności w stanie Baja California, Nuevo Leon, Jalisco i Morelos. Z kolei stany Chiapas i Puebla, charakteryzujące się wysokim poziomem korzystania z usług kulturalnych, cechowały się niskim poziomem wykształcenia, stosunkowo niską urbanizacją, wysokim odsetkiem zatrudnienia w rolnictwie oraz dużym odsetkiem licznych gospodarstw domowych. $\mathrm{W}$ tych stanach na wysoki poziom korzystania wpływ miały inne czynniki, nieuwzględnione w niniejszej analizie. W najsłabiej wypadającym stanie Coahuila zanotowano istnienie sprzyjających pod względem społecznym warunków dla korzystania (wysoki poziom urbanizacji i wykształcenia, niewielkie zatrudnienie w rolnictwie i przeciętny odsetek dużych gospodarstw domowych). Podobnie i w tym przypadku o tak niskim tym razem korzystaniu zadecydowały inne czynniki.

Na podstawie przeprowadzonych analiz stwierdzono, iż najlepiej wyposażonymi stanami w usługi kulturalne były stany położone na półwyspie Jukatan oraz wybrane stany położone w centralnej części kraju. Z kolei najlepszym korzystaniem charakteryzowała się stolica kraju (stan Distrito Federal) oraz - podobnie jak w przypadku dostępności - stany położone na Jukatanie i wybrane stany z centralnej części Meksyku. W części stanów poziom korzystania z usług kulturalnych był zawyżony w stosunku do prezentowanej dostępności do nich, w części był on zaniżony. Wpływ na taką sytuację miały m.in. czynniki społeczne.

\section{Literatura}

Bywalec Cz., Rudnicki L., 2002, Konsumpcja, PWE, Warszawa.

Estadísticas de Cultura, 2005a, Serie Boletín de Estadísticas Continuas, Demográficas y Sociales, Instituto Nacional de Estadística, Geografía e Informática, México.

Estadísticas de Cultura, 2005b, Cuaderno Núm. 8., Instituto Nacional de Estadística, Geografía e Informática, México.

Estadísticas de cultura, 2007, INEGI. Dirección General de Estadística. Dirección de Explotación de Registros Administrativos, México.

Indicatores, 2008, Instituto Nacional de Antropología e Historia, Consejo Nacional para la Kultura i las Artes, Mexico, za: Estadisticas de la Secretaria de Turismo (DATATUR), Coordinación Nacional de Desarrolló Institucional, México.

Prawelska-Skrzypek G., 2003, Polityka kulturalna polskich samorzqdów. Wybrane zagadnienia, Wyd. UJ, Kraków. 
Rutkowski J., 1984, Podstawowe pojęcia statystyki społecznej (dokończenie), Wiadomości Statystyczne, z. 11, GUS, Warszawa.

Styś A. red., 1992, Konsumpcja ustug w Polsce, Prace Naukowe, Akademia Ekonomiczna im. K. Adamieckiego, Katowice.

Werwicki A., 1998, Zmiany paradygmatu geografii ustug, ,, Przegląd Geograficzny” LXX, z. 3-4.

\section{Access to cultural services in Mexico}

The paper describes the availability of cultural services in Mexico. According to the research, the states featuring the most extensive array of cultural services are located in the Yucatan Peninsula and in selected parts of central Mexico. The places where cultural services are taken advantage of most extensively are the capital city (the state of Distrito Federal) as well as the previously mentioned states located in the Yucatan and in central Mexico. In some of the states, cultural services are available but not taken advantage of as much, while in other states, there are fewer cultural services, but they are extensively taken advantage of. In order to analyze this particular problem, values of cultural service use indicators were correlated with values of selected social indicators such as urbanization level, percentage of people with higher education, percentage of people employed in agriculture, forestry, and fishing, as well as percentage of large households.

dr Anna Winiarczyk-Raźniak

Uniwersytet Pedagogiczny im. Komisji Edukacji Narodowej w Krakowie

Instytut Geografii

e-mail: arazniak@poczta.fm 